\title{
Meteorological and glaciological evidence for different climatic variations on the east and west sides of the Lambert Glacier basin, Antarctica
}

\author{
XIAO Cunde, ${ }^{1,3^{*}}$ Ian ALLISON, ${ }^{2}$ REN Jiawen, ${ }^{3}$ QIN Dahe, ${ }^{3}$ ZHANG Mingjun, ${ }^{3}$ \\ LI Zhongqin ${ }^{3}$ \\ ${ }^{1}$ College of Physics, Peking University, Beijing 100871, China \\ E-mail: cdxiao@cams.cma.gov.cn \\ ${ }^{2}$ Australian Antarctic Division and Antarctic Climate and Ecosystems CRC, Private Bag 80, Hobart, \\ Tasmania 7001, Australia \\ ${ }^{3}$ Key Laboratory of Ice Core and Cold Regions Environment, Cold and Arid Regions Environmental and Engineering Research \\ Institute, Chinese Academy of Sciences, 260 Donggang West Road, Lanzhou 730000, China
}

\begin{abstract}
Surface mass-balance studies and climatic records from firn cores show remarkable differences between the east and west sides of the Lambert Glacier basin (LGB). The spatial distribution of the surface accumulation is influenced by the atmospheric moisture flux, and by the surface wind field, which is largely determined by topography. Atmospheric water-vapor budget data for the ice-sheet sector covering the basin $\left(45-90^{\circ} \mathrm{E}\right)$ show that on the east side of the LGB the moisture flux is poleward, averaging $18 \mathrm{~kg} \mathrm{~m}^{-1} \mathrm{~s}^{-1}$ in 1988, while for the west side it is Equatorward, averaging $5 \mathrm{~kg} \mathrm{~m}^{-1} \mathrm{~s}^{-1}$. A similar pattern, but with much lower transport of vapor flux, is seen across $70^{\circ} \mathrm{S}$. Two firn cores from the east side of the basin and two from the west side were analyzed to determine accumulation-rate and temperature-proxy variations for the past 50 years. The trends were opposite on the different sides of the basin. Similar opposing trends are seen in meteorological records from Davis and Mawson coastal stations, situated on the east and west sides of the LGB respectively. There is a good correlation between the accumulation $/{ }^{18} \mathrm{O}$ record in ice cores from the eastern LGB and the sea-level pressure (obtained from the US National Centers for Environmental Prediction/US National Center for Atmospheric Research (NCEP/NCAR) re-analyses) of a Southern Indian Ocean low (SIOL), but not between the SIOL and the records from the western LGB. This study reveals that variations in local circulation could alter at least the annual to decadal time-scale climate records, and may result in completely different climate histories between adjacent areas.
\end{abstract}

\section{INTRODUCTION}

Owing to the relatively short duration and sparse spatial coverage of Antarctic meteorological data, difficulties remain in explaining fully the history and forcing of the Antarctic surface mass balance. For instance, over recent decades to centuries, the records from different regions of the Antarctic ice sheet show large differences (e.g. Richardson and others, 1997). Although increasing accumulation rates have been reported for many sites (Pourchet and others, 1983; Peel and Mulvaney, 1988; Morgan and others, 1991; Mosley-Thompson and others, 1995), other sites show decreasing trends (Graf and others, 1990; Kameda and others, 1990; Bindschadler and others, 1993; Isaksson and Karlén, 1994; Ren and others, 1999). A similar situation is seen for isotope temperature records (Isaksson and others, 1996; Ren and others, 1999; Xiao and others, 2001). This complexity has been attributed to either a change in atmospheric circulation patterns, or post-depositional modification of the records by different meteorological factors operating in different regions. The International TransAntarctic Scientific Expedition (ITASE) program aims to investigate the decadal-to-centennial-scale climatic variations of the Antarctic ice sheet and to assess natural climate

*Present address: Chinese Academy of Meteorological Science, 46 Zhongguancun South Avenue, Beijing 100081, China. variability over several decades in order to better understand the global implications (Mayewski and Goodwin, 1999).

Within the framework of Chinese ITASE, several shallow cores were obtained along traverse lines during the 1996/97, 1997/98, 1998/99 and 2001/02 austral summers (Qin and others, 2000). Here, we discuss the spatial variations of the surface accumulation rate, as well as the variations of accumulation and a temperature proxy since the 1940s as deduced from cores recovered during Chinese or joint Australian-Chinese expeditions to the west and east sides of the Lambert Glacier basin (LGB; Fig. 1).

\section{DESCRIPTION OF DATA}

Lambert Glacier is one of the largest outlet glaciers in East Antarctica, draining a total area of $1.550 \times 10^{6} \mathrm{~km}^{2}$, including $71 \times 10^{3} \mathrm{~km}^{2}$ of floating ice in the Amery Ice Shelf (Fricker and others, 2002). The grounded portion of the Lambert-Amery system covers $16 \%$ of the grounded East Antarctic ice sheet, and has an estimated average surface mass balance of $87 \mathrm{~kg} \mathrm{~m}^{-2} \mathrm{a}^{-1}$ (Higham and Craven, 1997). The glacier is flanked along much of its length by the Prince Charles Mountains, and discharges into Prydz Bay via the Amery Ice Shelf (Fig. 1).

Stake measurements of surface mass balance along the Australian National Antarctic Research Expedition (ANARE) traverse route encircling the LGB were commenced in 1990. 
However, measurements along the whole ANARE route, including the east side, were only made for the 1994 season (Higham and others, 1997; Fig. 1). Subsequent Chinese National Antarctic Research Expedition (CHINARE) measurements on the east side were made from 1996 to 1998. In addition, a series of $1 \mathrm{~m}$ depth snow pits were sampled every $4 \mathrm{~km}$ along the coastal $476 \mathrm{~km}$ on the eastern-side route. These samples were analyzed to estimate the spatial distribution of $\delta^{18} \mathrm{O}$ and the accumulation rate.

During a joint Australian-Chinese oversnow traverse in 1992 on the west side of the LGB, two firn cores were drilled at MGA and LGB16 (Table 1), to 27 and $15.2 \mathrm{~m}$ depths, respectively. The cores were dated stratigraphically using isotopic profiles $\left(\delta^{18} \mathrm{O}\right)$, electrical conductivity measurements and visible stratigraphy. Snow-accumulation stake data (commencing in 1990) were additionally available as a reference every $2 \mathrm{~km}$ along the traverse route. A series of firn cores ( $\sim 10 \mathrm{~m}$ long) were drilled adjacent to each of the two sites to check the dating precision (Ren and others, 1999). During the 1996/97 and 1997/98 austral summers, a second pair of firn cores were extracted at DT001 and DT085 on the east side of the LGB (Table 1; Fig. 1). The depths of these were 50 and $52 \mathrm{~m}$, respectively. Isotope and chemical profiles $\left(\mathrm{Cl}^{-}, \mathrm{Na}^{+}\right.$and $\left.\mathrm{NO}_{3}{ }^{-}\right)$were used for cross-dating, and the precision is believed to be within \pm 2 years for the upper $20 \mathrm{~m}$ (Qin and others, 2000; Zhang and others, 2002). Only the top sections of these two cores, which roughly match the time periods corresponding to those of MGA and LGB16, were used in our comparison. The four cores were sampled every $3 \mathrm{~cm}$ in the laboratory.

We use estimates of the meridional moisture transport across $60^{\circ} \mathrm{S}$ in the Southern Ocean, derived by Slonaker and Van Woert (1999), to clarify the impact of the regional circulation on the distribution of accumulation for the ice sheet between $45^{\circ} \mathrm{E}$ and $90^{\circ} \mathrm{E}$. The subsector $45-70^{\circ} \mathrm{E}$ covers the western LGB, while $70-90^{\circ} \mathrm{E}$ covers the eastern LGB.

Meteorological data for Davis and Mawson stations have been extracted from the Australia Data Archive for Meteorology. Precipitation data are available for 25 years at Davis (though the record is not continuous), but no precipitation observations have been made at Mawson because of the

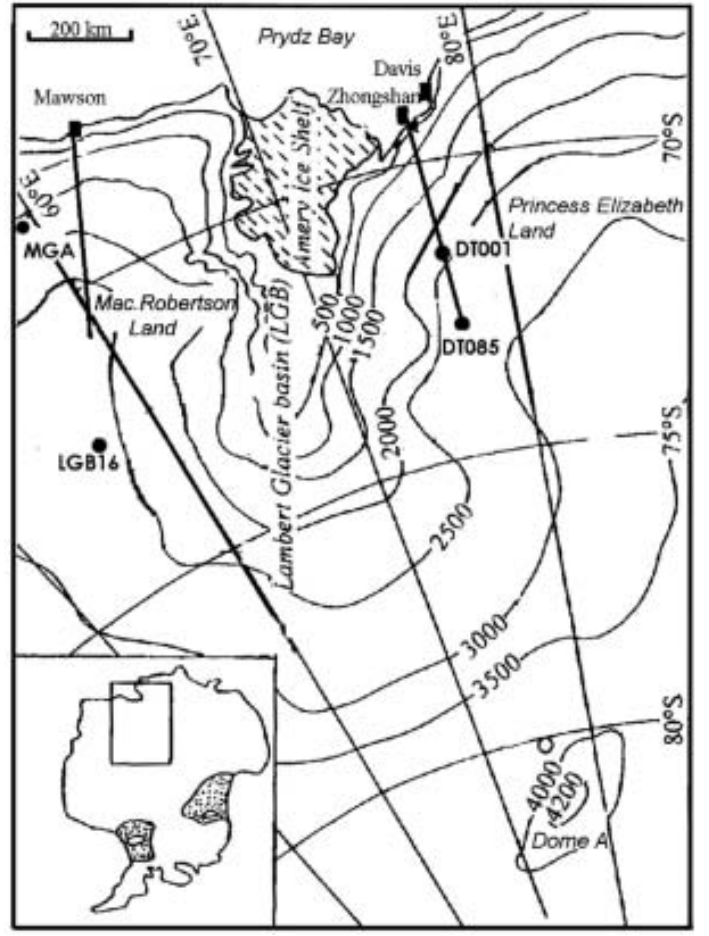

Fig. 1. Locations of firn cores (solid dots) from the LGB. The eastern and western LGB traverse lines are only shown for the initial $\sim 500 \mathrm{~km}$ (solid lines), accumulation distributions for which are discussed in the text.

strong drifting/blowing snow. Temperature records at Davis started in 1957 and have a gap from 1965 to 1968. Continuous temperature data are available from Mawson since 1954.

\section{RESULTS AND DISCUSSION}

In the following discussion, the accumulation distribution from the coast to the interior is compared for both sides of the LGB. Analyses of meridional moisture flux and meteorological evidence are used to interpret the spatial

Table 1. Rates of change in accumulation and $\delta^{18} \mathrm{O}$ records in firn cores from the east and west sides of the LGB

\begin{tabular}{|c|c|c|c|c|c|c|}
\hline Site & Location & Elevation & Period & $\begin{array}{l}\text { Mean } \\
\text { accumulation } \\
\text { rate (rate } \\
\text { of change } \\
\text { per year) }\end{array}$ & $\begin{array}{l}\text { Mean } \delta^{18} \mathrm{O} \\
\text { (rate of } \\
\text { change } \\
\text { per year) }\end{array}$ & Source \\
\hline & & ma.s.l. & & $\mathrm{kg} \mathrm{m}^{-2} \mathrm{a}^{-1}$ & $\%$ & \\
\hline
\end{tabular}

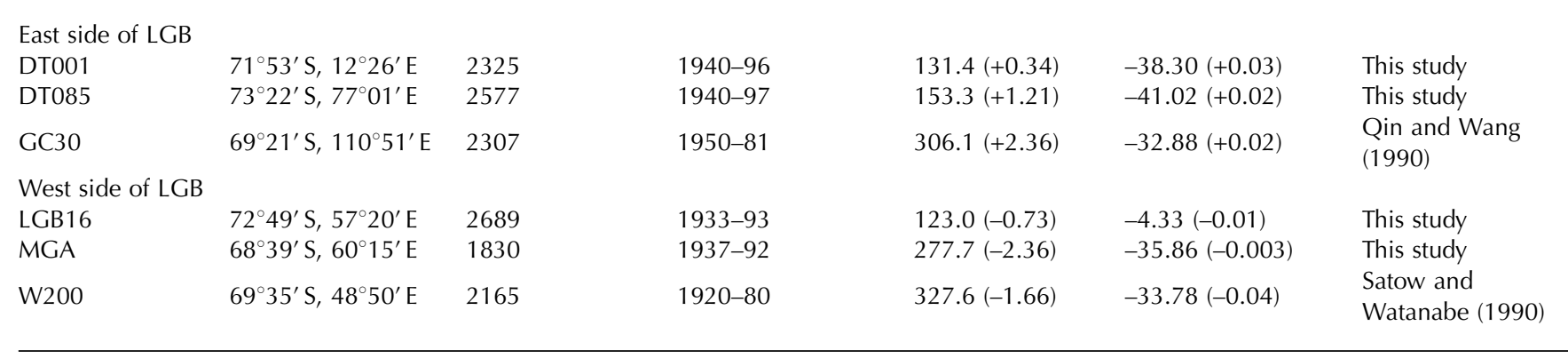



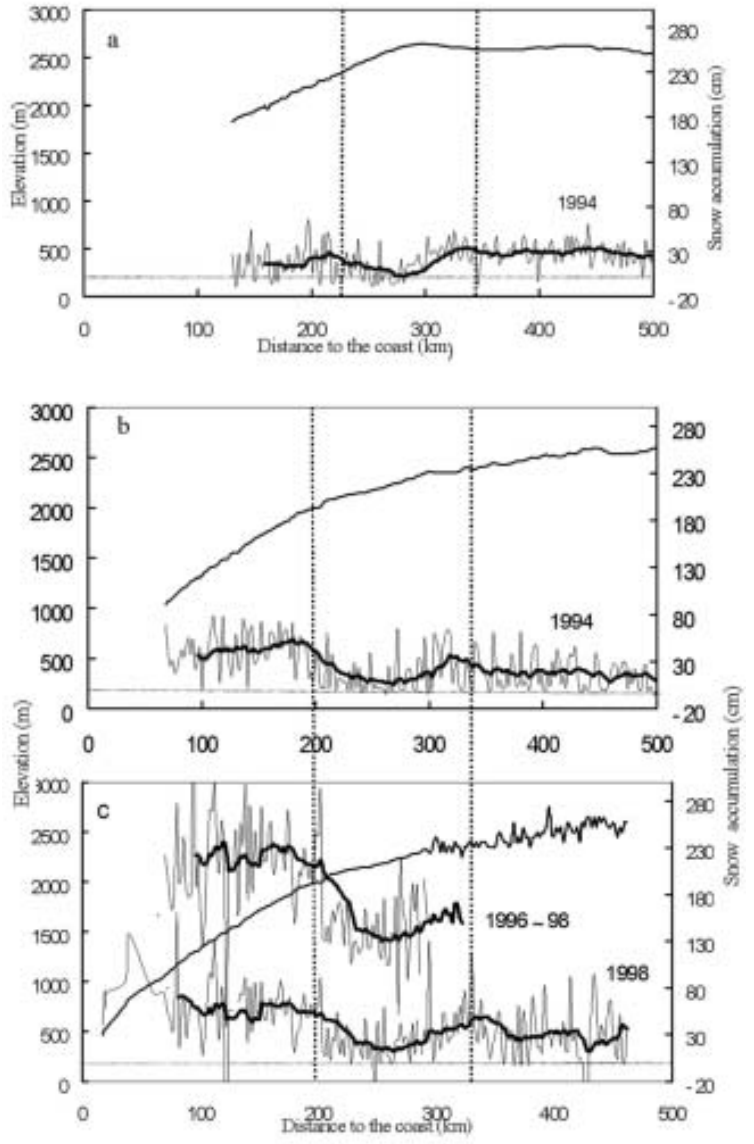

Fig. 2. Distribution of the 1994 surface accumulation along the initial $500 \mathrm{~km}$ traverse line over the western (a) and eastern LGB (b). Surface accumulation measurements in 1998 and the total values for 1996-98 along the eastern line are also shown (c). For the western LGB area, the measurements started at LGB00 $(\sim 130 \mathrm{~km}$ from the coast). The dense profiles are the 10-point smoothed variations. The dashed lines highlight the areas of minimum accumulation rate.

complexity of the accumulation distribution. Temperature proxy $\left(\delta^{18} \mathrm{O}\right)$ and accumulation recorded in the four cores are used to reveal temporal variations. Only the top sections of the cores, covering the last 50 years, are discussed in this study.

\section{Accumulation distribution and its relationship to atmospheric moisture fluxes}

The 1994 ANARE stake measurements around the entire LGB are used to investigate accumulation-rate differences between the two sides of the basin (Fig. 2a and b). The CHINARE stake data (Fig. 2c), with the measurement in 1996/97 covering $65-300 \mathrm{~km}$, and in 1998 covering the 0$476 \mathrm{~km}$ section of the line, are also shown. The ANARE and CHINARE data show a similar distribution on the east side, with a generally decreasing southward trend. This coincides with the pattern observed for most other coastal regions (Giovinetto and others, 1990). Based on all the ANARE and CHINARE observations, the average southward decrease in the snow accumulation rate for the eastern LGB is $52 \mathrm{~kg} \mathrm{~m}^{-2} \mathrm{a}^{-1}(100 \mathrm{~km})^{-1}$, which is similar to the gradient observed for Wilkes Land (Young and others, 1982) and Dronning Maud Land (Isaksson and Karlén, 1994). The stake

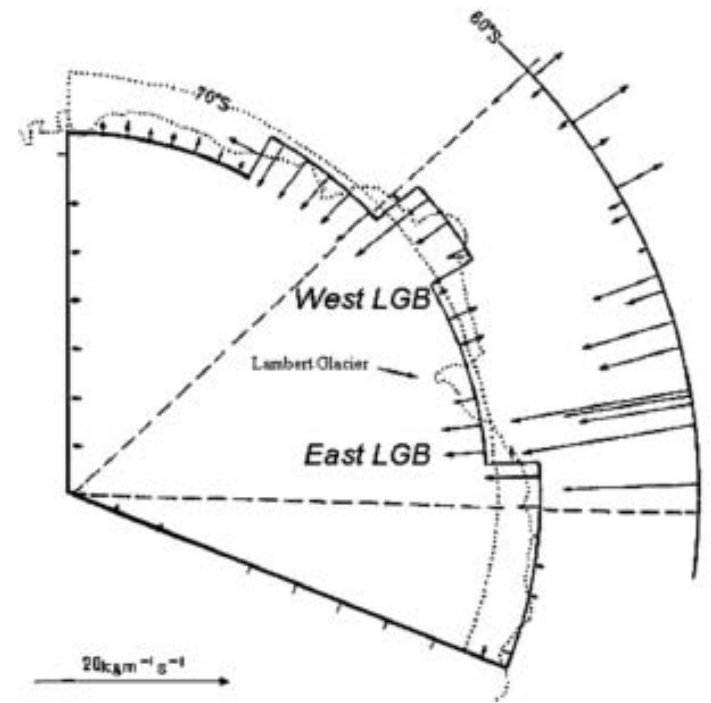

Fig. 3. Meridional moisture fluxes (in $\mathrm{kg} \mathrm{m}^{-1} \mathrm{~s}^{-1}$ ) across $60^{\circ} \mathrm{S}$ and $70^{\circ} \mathrm{S}$ latitude, for the sector $45-90^{\circ} \mathrm{E}$. The fluxes across $60^{\circ} \mathrm{S}$ are from Slonaker and Van Woert (1999). Fluxes across the angular heavy line (approximately $70^{\circ} \mathrm{S}$ ) are from Connolley and King (1996). The coastline is plotted as a dotted line.

measurements of accumulation rate along the eastern line agree with values derived from the snow-pit observations conducted every $2 \mathrm{~km}$, which show mean snow accumulation rates of $140-210 \mathrm{~kg} \mathrm{~m}^{-2} \mathrm{a}^{-1}$ for the segment of the route between 0 and $65 \mathrm{~km}$ from the coast, $70-140 \mathrm{~kg} \mathrm{~m}^{-2} \mathrm{a}^{-1}$ between 65 and $140 \mathrm{~km},<46 \mathrm{~kg} \mathrm{~m}^{-2} \mathrm{a}^{-1}$ between 140 and $280 \mathrm{~km}$, and $46-70 \mathrm{~kg} \mathrm{~m}^{-2} \mathrm{a}^{-1}$ between 280 and $500 \mathrm{~km}$.

However, on the west side in Mac. Robertson Land, a moderate mean accumulation of $72 \mathrm{~kg} \mathrm{~m}^{-2} \mathrm{a}^{-1}$ was observed for the coastal $200 \mathrm{~km}$, increasing to $88 \mathrm{~kg} \mathrm{~m}^{-2} \mathrm{a}^{-1}$ between 300 and $500 \mathrm{~km}$ inland. On both sides of the basin, the 200$300 \mathrm{~km}$ region is a transition zone between the coast and plateau, with a significant minimum in accumulation rate $\left(\sim 4 \mathrm{~kg} \mathrm{~m}^{-2} \mathrm{a}^{-1}\right)$. This region, on both sides, coincides with a divide in the ice surface topography, and the minima are probably due to divergence in moisture transport or in windblown snow redistribution. A similar dry belt with annual accumulation of $<5 \mathrm{~kg} \mathrm{~m}^{-2} \mathrm{a}^{-1}$ has been observed for other East Antarctic regions (Pettré and others, 1986; NIPR, 1997; Van den Broeke and others, 1999). We also notice that the accumulation rate is relatively higher on windward slopes than on leeward slopes, as has been reported for Wilkes Land (Goodwin, 1990).

The accumulation variation along the western LGB line differs from that of most coastal regions of the East Antarctic ice sheet, including the eastern LGB. We suggest that the difference in spatial variability between the eastern and western LGB is due to the differences in the main vapor transport paths that are determined by the mean atmospheric pressure field and modified by topography (Budd and others, 1995). On the west side of the LGB, the flattest region is around the head of the Amery Ice Shelf and therefore acts as a moisture channel. This would explain the higher accumulation in the middle of the western LGB traverse line, and the lower accumulation over the initial section.

Slonaker and Van Woert (1999) used satellite data to derive the three-dimensional atmospheric moisture and wind fields over the Southern Ocean for 1988, from which 

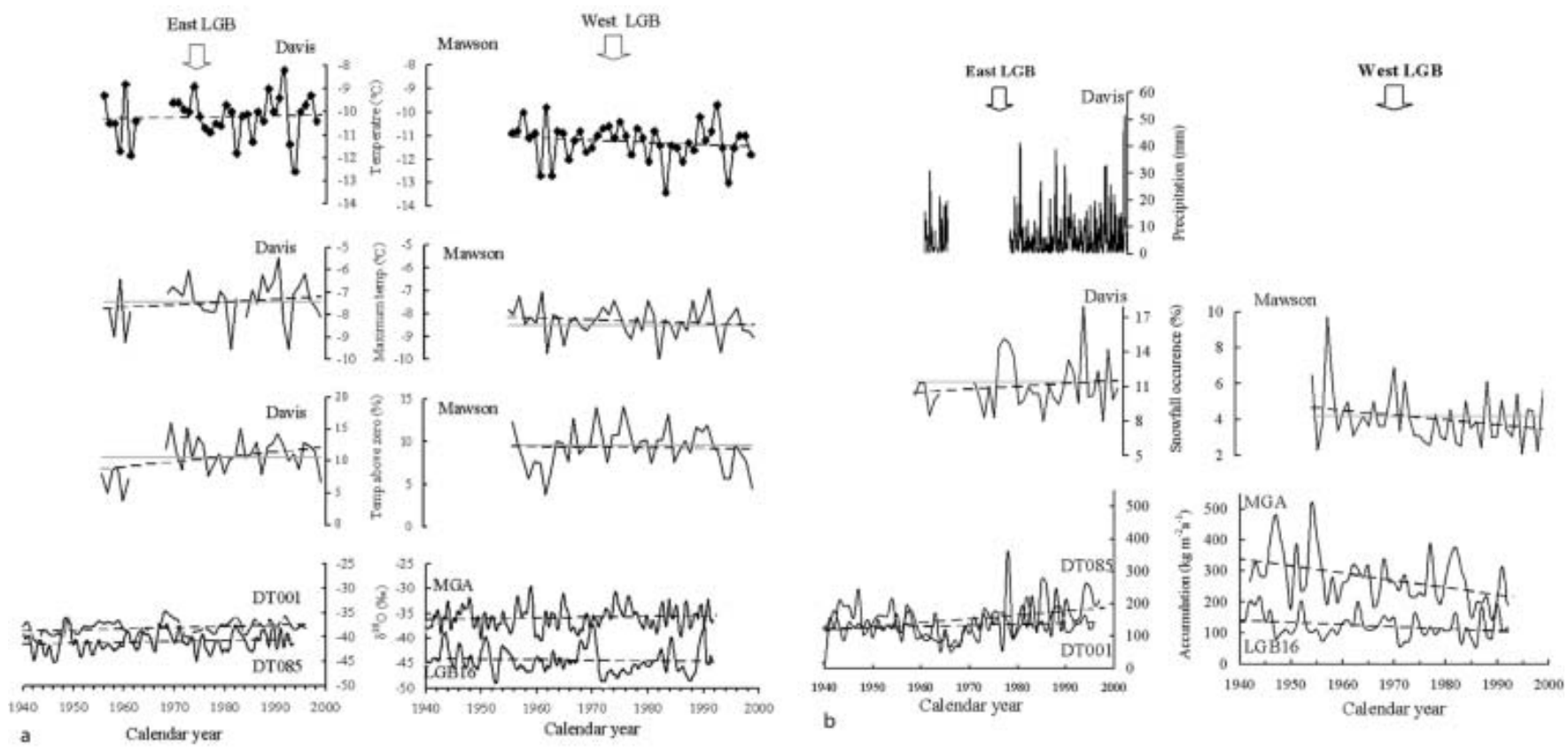

Fig. 4. (a) Firn-core records of $\delta^{18} \mathrm{O}$ (7-point smoothed) over the eastern and western LGB for the past 50 years (lowest panel). Instrumental surface temperature records at Davis and Mawson stations (upper panel), annual mean daily maximum temperature (second panel) and the annual percentage occurrence of temperature above $0^{\circ} \mathrm{C}$ (third panel) are shown for comparison. The dashed lines show the trends of variation from linear regressions, and the horizontal grey lines are the averages. (b) Firn-core records of annual accumulation rates over the eastern and western LGB for the past 50 years (lowest panel). Instrumental records of precipitation at Davis station (upper panel), and records of the annual percentage of snowfall occurrence at Davis and Mawson stations (middle panel) are shown for comparison. The dashed lines show the trends of variation from linear regressions.

they estimated water-vapor transport. They obtained moisture and vertical temperature fields from TIROS Operational Vertical Sounder (TOVS) instruments on board US National Oceanic and Atmospheric Administration (NOAA) satellites. The surface wind field over the ocean was derived from the Special Sensor Microwave/Imager (SSM/I) passive microwave instrument on Defense Meteorological Satellite Program (DMSP) satellites, and the winds at height were calculated from the thermal wind equation using the TOVSderived virtual temperature fields. We use their results for the meridional moisture flux across $60^{\circ} \mathrm{S}$ to clarify the vapor transport paths for the LGB. Moisture fluxes for the sector between $45^{\circ} \mathrm{E}$ and $90^{\circ} \mathrm{E}$ are shown in Figure 3. The moisture fluxes decrease sharply with elevation (Slonaker and Van Woert, 1999). The column-integrated moisture flux for the subsector from $70^{\circ} \mathrm{E}$ to $90^{\circ} \mathrm{E}$ averages $18 \mathrm{~kg} \mathrm{~m}^{-1} \mathrm{a}^{-1}$ poleward. However, for the subsector from $45^{\circ} \mathrm{E}$ to $70^{\circ} \mathrm{E}$ the average flux is $5 \mathrm{~kg} \mathrm{~m}^{-1} \mathrm{~s}^{-1}$ Equatorward. This is one of only two regions around the hemisphere where the moisture flux across $60^{\circ} \mathrm{S}$ is away from Antarctica. Moisture fluxes at specific locations are also in opposite directions on the east and west sides of the LGB: for example, $+2 \mathrm{~kg} \mathrm{~m}^{-1} \mathrm{~s}^{-1}$ (Equatorward) at $60^{\circ} \mathrm{E},+4 \mathrm{~kg} \mathrm{~m}^{-1} \mathrm{~s}^{-1}$ at $55^{\circ} \mathrm{E}$, but $-13 \mathrm{~kg} \mathrm{~m}^{-1} \mathrm{~s}^{-1}$ (poleward) at $80^{\circ} \mathrm{E}$.

Water-vapor transport across approximately $70^{\circ} \mathrm{S}$ (which approximates the average latitude of the Antarctic coast in the study region) for the sector from $2.4^{\circ} \mathrm{W}$ to $110.5^{\circ} \mathrm{E}$ was simulated by Connolley and King (1996) using the UKMO climate model. For this sector, between Sanae and Casey stations, data from eight coastal radiosonde stations are available to validate the modeled net moisture flux. These fluxes exhibit a similar pattern to those across $60^{\circ} \mathrm{S}$ for the same sector, but the magnitudes are much smaller. For instance, the flux between $70^{\circ} \mathrm{E}$ and $90^{\circ} \mathrm{E}$ is around $-5 \mathrm{~kg}$ $\mathrm{m}^{-1} \mathrm{a}^{-1}$, while between $60^{\circ} \mathrm{E}$ and $70^{\circ} \mathrm{E}$ it is $+1.5 \mathrm{~kg}$ $\mathrm{m}^{-1} \mathrm{~s}^{-1}$ (Fig. 3). The vapor transport over the coastal area of the basin displays a clockwise circulation. The interaction of eastward-moving cyclones over the high-latitude Southern Ocean with the topographic disruption of the LGB and the Prince Charles Mountains, for an otherwise uniform coast, induces clockwise moisture circulation in the region. Further, the pattern of winds over this area favors additional accumulation of drift snow on the west side of the LGB and a 'rain shadow' on the east (Allison, 1998).

In the following we discuss how this circulation pattern, combined with large-scale atmospheric phenomena such as the semi-annual oscillation (SAO), may lead to a remarkably different pattern of climatic variability over past decades between the two sides of the basin.

\section{Differences in recent decadal climate variability between the two sides of the LGB}

Large interannual temperature and accumulation-rate variability is known to complicate direct comparison between ice-core records from different sites (Morgan, 1985; MosleyThompson and others, 1990). Considering the different direction of net moisture transport and the different pattern of accumulation distribution between the two sides of the LGB, we might expect different climatic records in their icecore proxies.

In Figure 4, stable-isotope $\left(\delta^{18} \mathrm{O}\right)$ records from firn cores from each side of the LGB are compared with the meteorological records for the closest long-term station (Davis for east LGB, Mawson for west LGB). Davis has shown a warming of $0.2^{\circ} \mathrm{C}$ since 1957 , while Mawson has shown a cooling of $0.46^{\circ} \mathrm{C}$ since 1954 . The same trend is also seen in 
the annual mean daily maximum temperature (the rate is $+0.013^{\circ} \mathrm{Ca}^{-1}$ at Davis and $-0.01^{\circ} \mathrm{Ca}^{-1}$ at Mawson) as well as in the annual percentage occurrence of temperature above $0^{\circ} \mathrm{C}\left(+0.08 \% \mathrm{a}^{-1}\right.$ at Davis and $-0.007 \% \mathrm{a}^{-1}$ at Mawson).

The relationship between $10 \mathrm{~m}$ firm temperature and surface snow $\delta^{18} \mathrm{O}$ has a gradient of $1.19 \%{ }^{\circ} \mathrm{C}^{-1}$ for the eastern LGB and $1.67 \%{ }^{\circ} \mathrm{C}^{-1}$ for the western LGB. Hence the $\delta^{18} \mathrm{O}$ increases in DT001 and DT085 firn cores since 1940 would be equivalent to temperature increases of about $1.1^{\circ} \mathrm{C}$ and $1.4^{\circ} \mathrm{C}$ respectively over the period. A similar rate of increase has been reported in Dronning Maud Land (Isaksson and others, 1996). Conversely, the $\delta^{18} \mathrm{O}$ decreases in the MGA and LGB16 firn cores are equivalent to temperature decreases of about $0.1^{\circ} \mathrm{C}$ and $0.4^{\circ} \mathrm{C}$, respectively. We suggest that the reason for the difference between the two sides of the drainage area is that, on the east side of the LGB, increased inland moisture advection accompanies higher temperatures over the Southern Indian Ocean; while on the west side, as seen in Figure 3, the air-mass trajectories are not always directly from the coast to inland, weakening the link between $\delta^{18} \mathrm{O}$ and sea surface temperature. It should be noted that there is a similar pattern of $\delta^{18} \mathrm{O}$ fluctuation between DT001 and DT085, but not between MGA and LGB16 (Fig. 4a). We also note that the mean $\delta^{18} \mathrm{O}$ in the firn core at the western site LGB16 $(-44.3 \%)$ is somewhat lower than that for the eastern site DT085 (-41.0\%). After correction for the elevation difference between the sites, the isotope difference between LGB16 and DT085 is about $2 \%$. We suggest that much of the snow in the western LGB may derive from redistribution instead of directly from the ocean, and this may lead to the lower values of $\delta^{18} \mathrm{O}$ and a firn-core climate record that may be disturbed by local effects.

Accumulation variations in DT001 and DT085 firn cores, which have similar mean accumulation rates, exhibit similar patterns during the past half-century. However, accumulation changes in the two cores from the western LGB are not in phase during the past 50 years, possibly due to redistribution of surface snow (Fig. 4b). Figure $4 \mathrm{~b}$ also compares the accumulation histories from the four cores with the precipitation data from Davis and Mawson stations. A crude precipitation measurement has been made at Davis station since 1957, except for the period 1965-76. The monthly number of days when precipitation occurred is also shown in Figure 4 for both stations, but observations of precipitation have never been made at Mawson because of the high frequency of drifting/blowing snow compared to falling snow. A precipitation trend of roughly $+0.032 \mathrm{~mm} \mathrm{a}^{-1}$ is seen at Davis since 1957, with a more rapid rate of increase $\left(3.33 \mathrm{~mm} \mathrm{a}^{-1}\right)$ during the 1990s. The percentage of days of precipitation occurrence at Davis increased at $0.026 \% \mathrm{a}^{-1}$, whereas at Mawson the occurrence decreased at a rate of $0.027 \% \mathrm{a}^{-1}$.

The rates of change in $\delta^{18} \mathrm{O}$ and accumulation for the four cores are summarized in Table 1. Also shown are the results from another two cores: GC30 in Wilkes Land (east of the LGB) and W200 on the Mizuho Plateau (west of the LGB). These support the premise that the LGB is a boundary between different climate regimes for the East Antarctic ice sheet. Over the last 50 years, both $\delta^{18} \mathrm{O}$ and accumulation rate have increased over the eastern LGB, whereas both have decreased over the western LGB.

\section{Correlation of accumulation and temperature proxies with variation of the Southern Indian Ocean low}

Because large vertical and horizontal temperature gradients are constantly present between the continent and its immediate surroundings, near-surface temperature in Antarctica is very sensitive to changes in the low-level atmospheric circulation (Van den Broeke, 2000). The circulation system that has the largest impact on Antarctic temperature is the Southern Hemisphere semi-annual oscillation (SAO) (Van Loon, 1967; Van den Broeke, 1998), a twice-yearly contraction/expansion of the circumpolar low-pressure belt. Previous studies (e.g. Enomoto, 1991) have shown a close relationship between snow accumulation in East Antarctica and sea-level pressure (SLP) in the Southern Ocean, and also between the stable isotopes and the Southern Ocean surface temperature (Delmotte and others, 2000). The US National Centers for Environmental Prediction/US National Center for Atmospheric Research (NCEP/NCAR) re-analyses provide a record of $>50$ years of global analyses of atmospheric fields. These are available to support studies of the correlation between various historical climate proxy records on the global scale (Kistler and others, 2001).

We use the NCEP/NCAR re-analyses and the Climate Diagnostic Center Interactive Plotting and Analysis tools to investigate the correlation between SLP and the accumulation rates over the eastern (Fig. 5a) and western LGB (Fig. 5c) since 1948. A significant $(|r|>0.3, \alpha=0.01)$ negative correlation exists between DT001 accumulation change and a Southern Indian Ocean low (SIOL), which lies to the north of Prydz Bay, but there is no correlation between the LGB16 accumulation and the SIOL. This suggests direct moisture supply from the SIOL to the eastern LGB, but not to the western LGB. Similarly, a high positive correlation is found between the DT001 $\delta^{18} \mathrm{O}$ series and the surface temperature of the Southern Indian Ocean (Fig. 5b). A similar result is found between Law Dome ice-core $\delta^{18} \mathrm{O}$ series and the temperature of the adjacent ocean there (Delmotte and others, 2000). But again, no significant correlation is found for the LGB16 $\delta^{18} \mathrm{O}$ record (Fig. $5 \mathrm{~d}$ ).

Van den Broeke's (2000) calculation based on the SAO shows that locally enhanced advection of air from the icesheet interior has caused strong cooling in the western LGB since the 1950s, but low-level warming over continental Antarctica and coastal Victoria Land and Princess Elizabeth Land, at both the $800 \mathrm{hPa}$ and $2 \mathrm{~m}$ level. Van den Broeke also found that temperature change at coastal Antarctic stations carries the fingerprint of warming/cooling since mid-1970. Our study supports Van den Broeke's (2000) conclusions.

\section{CONCLUSIONS}

Lambert Glacier, the Amery Ice Shelf and the Prince Charles Mountains form a major north-south topographic feature in the East Antarctic ice sheet, and this region is also a significant boundary between different climate regimes. There is a large-scale atmospheric transport of moisture towards the interior of the ice sheet across both $60^{\circ} \mathrm{S}$ and $70^{\circ} \mathrm{S}$ on the east side of the basin, but the moisture transport is away from Antarctica on the west. This clockwise circulation of air masses results in a difference in the spatial distribution of surface accumulation. The accumulation rate decreases towards the south, as it does for most ice-sheet coastal regions, but on the western flank of the LGB there is 

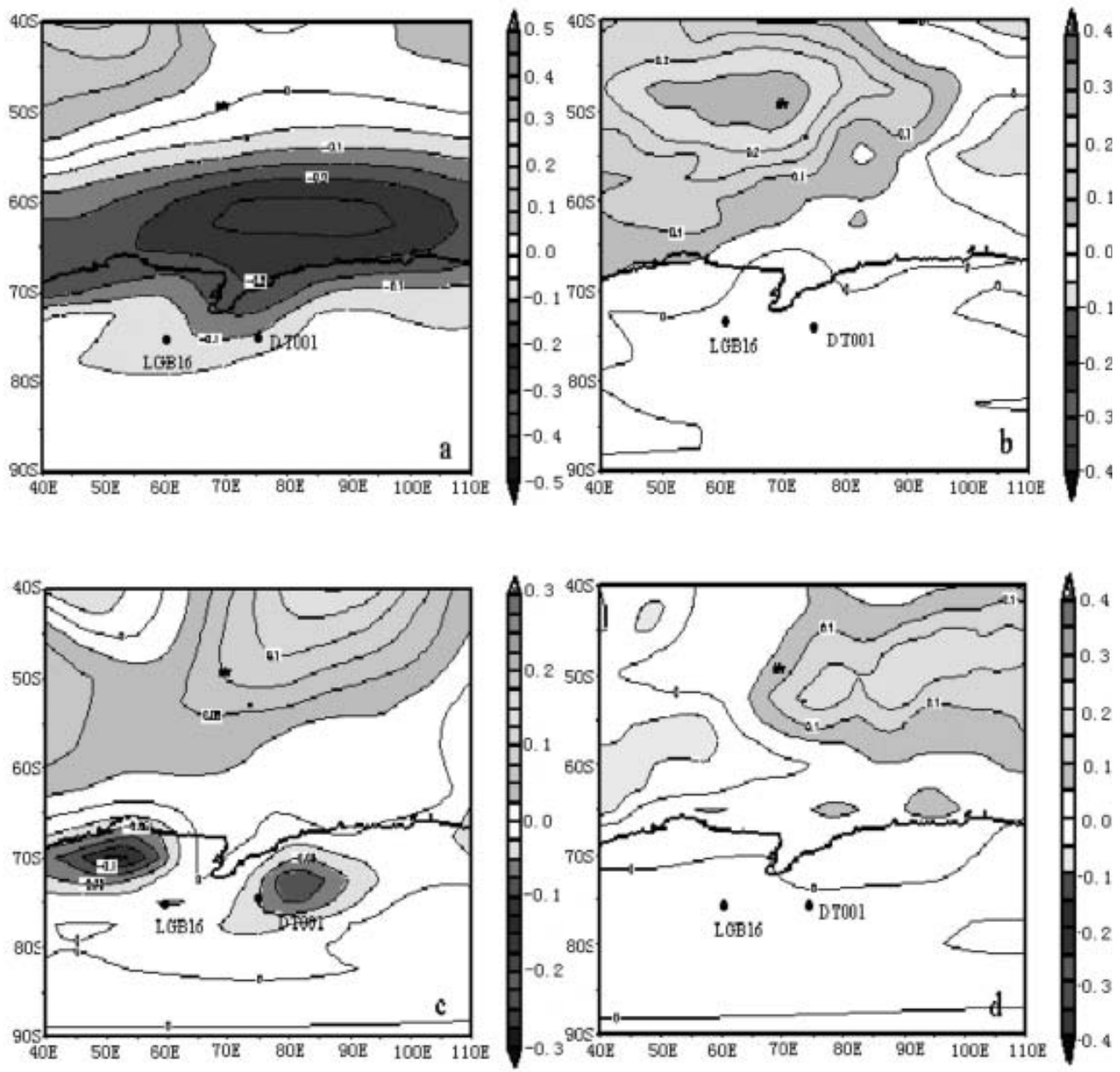

Fig. 5. Correlation of DT001 (a) and LGB16 (c) accumulation with SLP, and the correlation of DT001 (b) and LGB16 (d) $\delta^{18} \mathrm{O}$ with surface air temperature from the NCEP/NCAR numerical re-analyses. The time-spans of the correlations depend on when the cores were drilled: they are 1948-96 for DT001 and 1948-92 for LGB16.

a slight tendency for the rate to increase with distance south over the first $500 \mathrm{~km}$.

Firn cores from the east and west of the basin show opposite trends in both stable-isotopic temperature and accumulation variation over the past 50 years. On the east side, temperatures have warmed and accumulation has increased, whereas in the west, temperatures have cooled and accumulation has decreased. Different cores from the east side show a similar pattern of variability since the 1940s, but on the west, separate core records are not well correlated, possibly because of the impact of snow redistribution. In the east, where the moisture transport is from the ocean to the ice sheet, there is a negative correlation between accumulation change and a SIOL which lies to the north of Prydz Bay, and positive correlation between changes to $\delta^{18} \mathrm{O}$ in surface snow and the sea surface temperature in the same region. These relationships are not seen in the west. The opposing trends in temperature and precipitation are also evident in meteorological observations from Davis (east) and Mawson (west) since the 1950s.

A changed circulation pattern for coastal Antarctica may explain the different decadal climate variability on the two flanks of the LGB. The position and strength of the SIOL plays an important role in climate variability for the eastern LGB. This study suggests that in some regions, such as the LGB, complex local circulation, rather than large-scale continental or global circulation, may regulate the climate of the ice sheet.

\section{ACKNOWLEDGEMENTS}

The authors are grateful to the staff of the Office of Chinese Polar Administration for establishing the field logistics. We would like to thank R. Slonaker, now at Raytheon ITSS Corporation, for providing the moisture flux data, and D. Shepherd and $\mathrm{H}$. Hutchinson at the Bureau of Meteorology, Australia, for providing the meteorological data for Davis and Mawson stations. This work is supported by the National Natural Science Foundation of China (40305007), the Ministry of Science and Technology of China (2001CB711003, 2001DIA50040) and the Chinese Academy of Sciences (KZCX2-303).

\section{REFERENCES}

Allison, I. 1998. Surface climate of the interior of the Lambert Glacier basin, Antarctica, from automatic weather station data. Ann. Glaciol., 27, 515-520.

Bindschadler, R., P.L. Vornberger and S. Shabtaie. 1993. The detailed net mass balance of the ice plain on Ice Stream B, Antarctica: a geographic information system approach. J. Glaciol., 39(133), 471-482. 
Budd, W. F., P. A. Reid and L. J. Minty. 1995. Antarctic moisture flux and net accumulation from global atmospheric analyses. Ann. Glaciol., 21, 149-156.

Connolley, W.M. and J.C. King. 1996. A modeling and observational study of East Antarctic surface mass balance. J. Geophys. Res., 101(D1), 1335-1344.

Delmotte, M., V. Masson, J. Jouzel and V.I. Morgan. 2000. A seasonal deuterium excess signal at Law Dome, coastal eastern Antarctica: a Southern Ocean signature. J. Geophys. Res., 105(D6), 7187-7197.

Enomoto, H. 1991. Fluctuations of snow accumulation in the Antarctic and sea level pressure in the Southern Hemisphere. Climatic Change, 18(1), 67-87.

Fricker, H.A. and 9 others. 2002. Redefinition of the grounding zone of the Amery Ice Shelf, East Antarctica, grounding zone. J. Geophys. Res., 107(B5). (10.1029/2001JB000383.)

Giovinetto, M. B., N. M. Waters and C. R. Bentley. 1990. Dependence of Antarctic surface mass balance on temperature, elevation, and distance to open ocean. J. Geophys. Res., 95(D4), 3517-3531.

Goodwin, I. D. 1990. Snow accumulation and surface topography in the katabatic zone of eastern Wilkes Land, Antarctica. Antarct. Sci., 2(3), 235-242.

Graf, W., O. Reinwarth, H. Oerter and M. Dyurgerov. 1990. Isotopic and stratigraphical interpretation of a $16 \mathrm{~m}$ firn core nearby Druzhnaya I. In Miller, H., ed. Filchner-Ronne-IceShelf-Programme. Report No. 4 (1990). Bremerhaven, Alfred Wegener Institute for Polar and Marine Research, 46-49.

Higham, M. and M. Craven. 1997. Surface mass balance and snow surface properties from the Lambert Glacier basin traverses 1990-94. Hobart, Tasmania, Cooperative Research Centre for the Antarctic and Southern Ocean Environment. (Research Report 9.)

Higham, M., M. Craven, A. Ruddell and I. Allison. 1997. Snowaccumulation distribution in the interior of the Lambert Glacier basin, Antarctica. Ann. Glaciol., 25, 412-417.

Isaksson, E. and W. Karlén. 1994. Spatial and temporal patterns in snow accumulation, western Dronning Maud Land, Antarctica. J. Glaciol., 40(135), 399-409.

Isaksson, E., W. Karlén, N. Gundestrup, P. Mayewski, S. Whitlow and M. Twickler. 1996. A century of accumulation and temperature changes in Dronning Maud Land, Antarctica. J. Geophys. Res., 101(D3), 7085-7094.

Kameda, T., M. Nakawo, S. Mae, O. Watanabe and R. Naruse. 1990. Thinning of the ice sheet estimated from total gas content of ice cores in Mizuho Plateau, East Antarctica. Ann. Glaciol., 14, 131-135.

Kistler, R. and 12 others. 2001. The NCEP/NCAR 50-year reanalysis: monthly means CD-ROM and documentation. Bull. Am. Meteorol. Soc., 82(2), 427-467.

Mayewski, P. A. and I. Goodwin. 1999. Antarctic's role pursued in global climate change. Eos, 80(35), 398-400.

Morgan, V. I. 1985. An oxygen isotope-climate record from the Law Dome, Antarctica. Climatic Change, 7(4), 415-426.

Morgan, V. I., I. D. Goodwin, D. M. Etheridge and C. W. Wookey. 1991. Evidence from Antarctic ice cores for recent increases in snow accumulation. Nature, 354(6348), 58-60.
Mosley-Thompson, E., L. G. Thompson, P.M. Grootes and N. Gundestrup. 1990. Little Ice Age (neoglacial) paleoenvironmental conditions at Siple Station, Antarctica. Ann. Glaciol., 14, 199-204.

Mosley-Thompson, E. and 6 others. 1995. Recent increase in South Pole snow accumulation. Ann. Glaciol., 21, 131-138.

National Institute of Polar Research (NIPR). 1997. Antarctica: East Queen Maud Land/Enderby Land glaciological folio. Tokyo, National Institute of Polar Research.

Peel, D. A. and R. Mulvaney. 1988. Air temperature and snow accumulation in the Antarctic Peninsula during the past 50 years. [Abstract.] Ann. Glaciol., 11, 207.

Pettré, P., J. F. Pinglot, M. Pourchet and L. Reynaud. 1986. Accumulation distribution in Terre Adélie, Antarctica: effect of meteorological parameters. J. Glaciol., 32(112), 486-500.

Pourchet, M., J. F. Pinglot and C. Lorius. 1983. Some meteorological applications of radioactive fallout measurements in Antarctic snows. J. Geophys. Res., 88(C10), 6013-6020.

Qin, D. and W. Wang. 1990. The historical climatic records in ice cores from the surface layer of Wilkes Land, Antarctic. Science in China, Ser. B, 33(4), 460-466.

Qin Dahe and 8 others. 2000. Primary results of glaciological studies along an $1100 \mathrm{~km}$ transect from Zhongshan station to Dome A, East Antarctic ice sheet. Ann. Glaciol., 31, 198-204.

Ren Jiawen, Qin Dahe and I. Allison. 1999. Variations of snow accumulation and temperature over past decades in the Lambert Glacier basin, Antarctica. Ann. Glaciol., 29, 29-32.

Richardson, C., E. Aarholt, S.-E. Hamran, P. Holmlund and E. Isaksson. 1997. Spatial distribution of snow in western Dronning Maud Land, East Antarctica, mapped by a groundbased snow radar. J. Geophys. Res., 102(B9), 20,343-20,353.

Satow, K. and O. Watanabe. 1990. Seasonal variation of oxygen isotopic composition of firn cores in the Antarctic ice sheet. Ann. Glaciol., 14, 256-260.

Slonaker, R. and M.L. Van Woert. 1999. Atmospheric moisture transport across the Southern Ocean via satellite observations. J. Geophys. Res., 104(D8), 9229-9249.

Van den Broeke, M.R. 1998. The semiannual oscillation and Antarctic climate. Part 1: influence on near-surface temperatures (1957-1979). Antarct. Sci., 10(2), 175-183.

Van den Broeke, M. R. 2000. On the interpretation of Antarctic temperature trends. J. Climate, 13(21), 3885-3889.

Van den Broeke, M. R. and 6 others. 1999. Climate variables along a traverse line in Dronning Maud Land, East Antarctica. J. Glaciol., 45(150), 295-302.

Van Loon, H. 1967. The half-yearly oscillations in middle and high southern latitudes and the coreless winter. J. Atmos. Sci., 24(5), 472-486.

Xiao Cunde, Ren Jiawen, Qin Dahe, Li Hongqin, Sun Weizhen and I. Allison. 2001. Correspondence. Complexity of the climatic regime over the Lambert Glacier basin of the East Antarctic ice sheet: firn-core evidences. J. Glaciol., 47(156), 160-162.

Young, N.W., M. Pourchet, V.M. Kotlyakov, P. A. Korolev and M. B. Dyurgerov. 1982. Accumulation distribution in the IAGP area, Antarctica: $90^{\circ} \mathrm{E}-150^{\circ} \mathrm{E}$. Ann. Glaciol., 3, 333-338.

Zhang, M.J. and 6 others. 2002. A continuous 250-year record of volcanic activity from Princess Elizabeth Land, East Antarctica. Antarct. Sci., 14(1), 55-60. 